\title{
Control of the number of field slugs Deroceras agreste $L$. in the plantations of garden strawberry
}

\author{
Marina Podgornaya, Nadezhda Didenko, Anfisa Vasilchenko, Julia Kashchits, and \\ Irina Mishchenko \\ ${ }^{1}$ Federal State Budget Scientific Institution «North Caucasian Federal Scientific Center of Horticulture, \\ Viticulture, Wine-making», 39 str. 40 Let Pobedy, Krasnodar, 350901, Russia
}

\begin{abstract}
Slugs cause serious harm to nurseries and young plantations of fruit and berry crops in the Krasnodar region. On garden strawberries, the most common species is the field slug Deroceras agreste L., whose larvae damage ripe fruits and leaves, as well as contaminate them with their secretions and mucus, which leads to a decrease in the quality of seedlings and contributes to damage by secondary pests. In modern protection systems, the most commonly used pest control systems are molluscicides containing methaldehyde. The aim of our research was to assess the biological effectiveness of the molluscicides Sliznyakoff, G $(60 \mathrm{~g} / \mathrm{kg}$ methaldehyde) and Slizneed, G (60 g/kg methaldehyde) in controlling the abundance of field slugs in strawberry agrocenoses on the Clery variety. It was found that with an average number of phytophage larvae in the control variant (12.5-16.0 individuals $/ 10 \mathrm{~m}^{2}$ ), a single use of molluscicides causes $95.3 \%$ mortality of $D$. agreste $\mathrm{L}$. on the 7 th day.
\end{abstract}

\section{Introduction}

Slugs pose a major hazard not only to young plantations of fruit and berry crops, but also cause serious harm in nurseries and mother plantations. On strawberries, garden slugs damage ripe fruits and leaves, as well as pollution them with their secretions and mucus, which leads to a decrease in the quality of seedlings and contributes to damage by secondary pests $[1,2]$. With a high number of slugs, they can completely destroy the nursery or young plantings of fruit, berry and ornamental crops. In garden agrocenoses, besides the field slug Deroceras agreste L., there are other types of slugs - reticulated Deroceras reticulatum, smooth Deroceras laeve, as well as brown slug Deroceras panormitanum and garden arion Arion middleus [3].

Molluscs do damage to in areas with annual precipitation over 500-650 mm, which includes the Krasnodar region. It is known from the scientific literature that the most common methods for controlling slugs are agrotechnical: loosening the soil, combating weeds, draining wetlands, thinning thickened plantings, etc.; mechanical - manual collection or catching with the help of artificial shelters; chemical - the use of chemical granules containing metaldehyde or carbamates (methiocarb or thiodicarb) [4, 5]. Molluscs contact with drugs through food intake or skin contact, which increases the secretion from the mucous cells of the slug, leading to dehydration, seizures and death $[6,7,8]$. 
The foreign scientific literature provides data on testing the Baitchain molluscicidal system to control the number of slugs in fruit plantations and nurseries by a physicochemical method. These are metaldehyde granules located on a cord for tying around the base of tree trunks. The results were compared with traditional metaldehyde, granules (Sluggit) of which were applied to the soil surface. It has been found that significant mortality of slugs is achieved when Baitchain is used alone or in combination with Sluggit. This technology is recommended as a comprehensive slug control strategy in South Africa as well as other parts of the world [9].

Metaldehyde is by far the most abundant active ingredient in slug pellets. Approximately $22,000 \mathrm{~kg}$ are used each year in the United States alone. The presence of residues of metaldehyde in crops in the United States is completely prohibited, because when precipitation falls, it often enters water bodies, where it causes the death of aquatic wildlife [10, 11].

In accordance with Article 12 of Regulation (EC) No 396/2005, the European Food Safety Authority (EFSA) revised Maximum Residue Levels (MRLs), the metaldehyde content of garden strawberries is now $0.1 \mathrm{mg} / \mathrm{kg}$ [12]. The standards PP 1/95 Slugs for vegetables, strawberries and ornamental plants and PP 1/96 Slugs for field crops have been combined and revised, it is recommended to reduce the MRL for strawberries to $0.05 \mathrm{mg} / \mathrm{kg}$ [13].

The objective of our research was to evaluate the biological effectiveness of the molluscicides Sliznyakoff, G (60 g / kg metaldehyde) and Slizneed, G (60 g / kg metaldehyde) in controlling the number of field slugs in strawberry agrocenoses of the Krasnodar region.

\section{Materials and methods}

The studies were carried out during 2018-2019. in nursery plantations of garden strawberries at ZAO EPF "Tsentralnoe", Krasnodar, Russia. A microplot field trial to determine the biological effectiveness of molluscicides against the field slug Deroceras (Agriolimax) agreste L. was established on the Clery cultivar of 2017, the size of the variant was $40 \mathrm{~m}^{2}$, the replication was 4 -fold, the placement was randomized. The preparations were introduced once in the phase of culture development (BBCN scale) - the 85th stage of the berry takes on a variety-typical color, by manually sieving granules on the soil surface in the aisles and along the perimeter of the experimental plot. In the experiment, we used a preparation based on metaldehyde Sliznyakoff, G $(60 \mathrm{~g} / \mathrm{kg})$ with a consumption rate of $30 \mathrm{~g} / 10 \mathrm{~m}^{2}$. As a standard, we used the mollusccide Sluzneed, G (60 g/ kg), approved for use on strawberries. In the control variant, the treatments were carried out with water. The mechanism of action of the tested drugs: with the obligatory presence of water in the stomachs of slugs and snails, metaldehyde is converted into acetaldehyde, as a result of which the phytophages stop moving and feed, lose their turgor and fall from the strawberry leaves to the ground. The counting of the number and determination of the biological efficiency was carried out on the $3 \mathrm{rd}, 7 \mathrm{th}, 14 \mathrm{th}$ and 21 st days after application, and also the number of slugs was established before the introduction of granules $[14,15]$.

\section{Results and discussion}

The field slug overwinters in the egg stage in the soil; in the Krasnodar region, the larvae from eggs hatch in late April - early May. The optimal development regime is observed at a temperature of $+16^{\circ} \mathrm{C}-18^{\circ} \mathrm{C}$. An increase in temperature above $+26^{\circ} \mathrm{C}$ leads to a suspension of feeding and growth of larvae, and then to death. Larvae of D. agreste L. are responsive and to negative temperatures, when it drops to minus $4.5^{\circ} \mathrm{C}$, slugs die. However, the most important indicator in slug biology is air humidity. The optimum humidity for 
reproduction and growth is $90 \%$, field slugs are able to withstand water loss up to $50 \%$ of their body weight. The increase in the number of slugs in our region in the last two years is associated with mild and warm winters, a short-term decrease in temperature below minus $5.0^{\circ} \mathrm{C}$ during this period was observed for 1-2 days.

Increase in temperature (by 2-3.7 ${ }^{\circ} \mathrm{C}$ ) and air humidity (up to 66-77\%) in April-May 2018-2019 led to earlier (at the beginning of the first decade of May) hatching of field slug larvae. The abundance of phytophage before the experiment was 11.0-11.5 larvae per $10 \mathrm{~m}^{2}$ (Fig. 1).

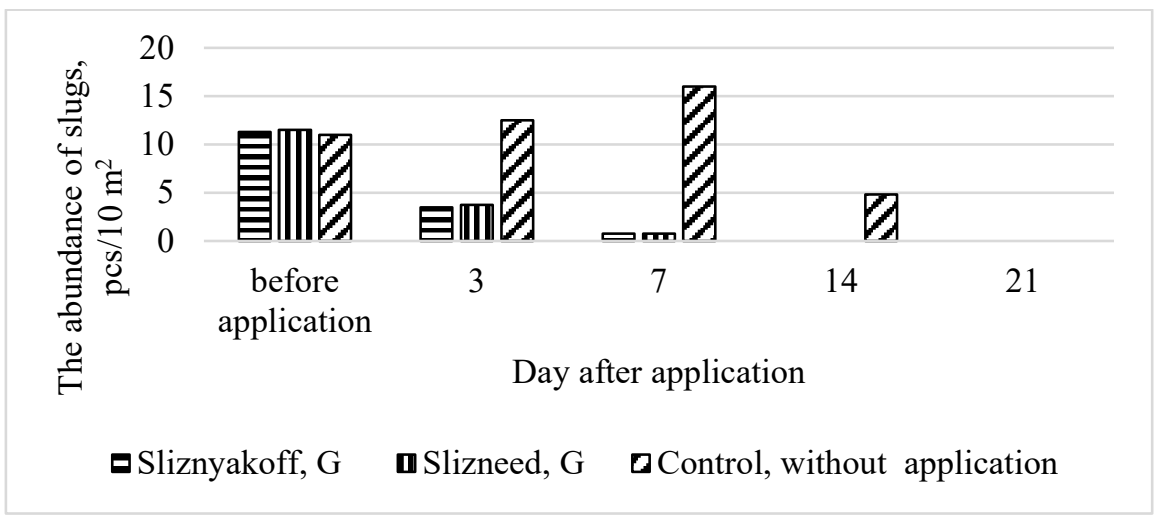

Fig. 1. The number of field slug Deroceras (Agriolimax) agreste L. on the experimental plot of garden strawberry, variety Clery

On the third day after the introduction in the variant Sliznyakoff, G (60 g / kg), the biological effectiveness (BE) was $72.0 \%$, which is $2 \%$ higher than the indicators obtained in the standard variant when using Sluzneed, G. In the control variant during this period, an increase in the number of field slug larvae by 1.5 individuals per $10 \mathrm{~m}^{2}$ was noted. On the seventh day, BE increased by $23.3 \%$ in the variant Sliznyakoff, G $(60 \mathrm{~g} / \mathrm{kg})$ and amounted to $95.3 \%$, which is identical to the indicators of the standard; in the control variant, the number of individuals increased to $16.0 / 10 \mathrm{~m}^{2}$. In 1-2 decades of June, an increase in air temperature to $25-27^{\circ} \mathrm{C}$ was recorded, which led to a 3.3-fold decrease in the number of pests in the control variant; in the experimental variants, not one field slug larva was found. An increase in temperature in the third decade of June to $30^{\circ} \mathrm{C}$ and above led to the complete death of $D$. agreste $L$. larvae in the control variant (Fig. 2).

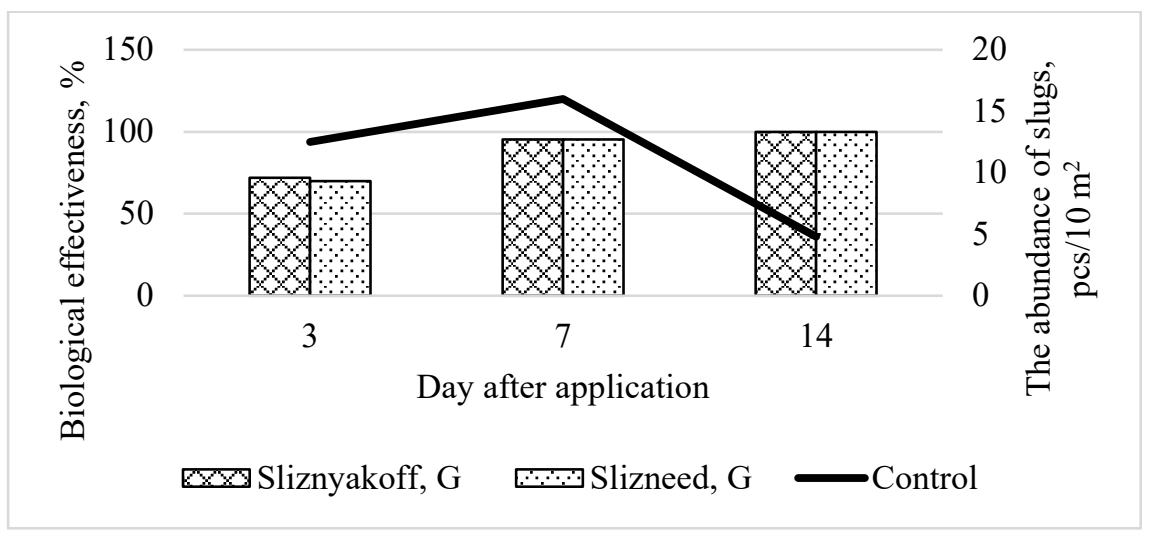

Fig. 2. Biological efficacy of mollucacides against the field slug Deroceras (Agriolimax) agreste L. on garden strawberries, variety Clery 
Thus, in the Kuban zone of the central horticultural subzone of Krasnodar region the biological effectiveness of the molluscicides Sliznyakoff, G and Slizneed, G (60 g/ $\mathrm{kg}$ metaldehyde) made assessement on strawberries of the garden variety Clery against the larvae of the field slug Deroceras (Agriolimax) agreste L. With an average number of phytophage larvae in the control variant (12.5-16.0 individuals $\left./ 10 \mathrm{~m}^{2}\right)$, the effectiveness of the molluscicide Sliznyakoff, G (60 g / kg metaldehyde) on the 7th day was $95.3 \%$, which corresponds to the indicators obtained in standard. The next stage of our research is planned to reveal the content of residual amounts of metaldehyde in the berries of garden strawberries.

\section{References}

1. H. Burrack, A. Toennisson, NC State Extension Publications (2014). https://content.ces .ncsu.edu/slugs-in-strawberries

2. D. Dörler, M. Kropf, G. Laaha, J.G. Zaller, BMC Ecol., 18, 23 (2018). https://doi.org/10.1186/s12898-018-0179-7

3. A. Pieterse, A.P. Malan, J.L. Ross, Insects, 11(7), 437 (2020). https://doi.org/10.3390/insects11070437

4. J. Kozłowski, T. Kałuski, M. Jaskulska, M. Kozłowska, J. Plant Protection Res., 50(4), 520-526 (2010). https://doi.org/10.2478/v10045-010-0086-1

5. M. J. Wilson, D. J. Wilson, G. Burch, B. Cotching, New Zealand Agron., 44, 95-101 (2014). https://www.researchgate.net/publication/301512914_Effects_of_simulated rainfall on two contrasting metaldehyde_slug_baits

6. M. Nash, GRDC (2016). https://grdc.com.au/resources-and-publications/grdc-updatepapers/tab-content/grdc-update-papers/2016/07/new-insights-into-slug-control

7. M. R. Douglas, J. F. Tooker, J. Integr. Pest Manag., 3(1), 1-9 (2012). https://doi.org/ $\underline{10.1603 / \mathrm{IPM} 11023}$

8. G. D. Castle, G. A. Mills, A. Gravell, L. Jones, I. Townsend, D. G. Camerone, G. R. Fones, Environ. Sci.: Water Res. Technol., 3, 415-428 (2017). https://doi.org/ 10.1039/C7EW00039A

9. A. Santacruz, M.P. Toro, C.G. Salazar, Agron. colomb. 29(2), 241-247 (2011) http://www.scielo.org.co/pdf/agc/v29n2/v29n2a10.pdf

10. K.J. Gething, A. Pickwell, R.P. Chadd, P.J. Wood, Environ. Pollut., 265(A), 115015 (2020). https://doi.org/10.1016/j.envpol.2020.115015

11. PPDB: Pesticide Properties DataBase, (2016). http://sitem.herts.ac.uk/aeru/ppdb/ en/index.htm

12. EFSA (European Food Safety Authority), EFSA J. 12 (5), 3682 (2014). https://doi.org/10.2903/j.efsa.2014.3682

13. Normes OEPP EPPO Standards, EPPO Bull. 45(3), 351-358 (2015). https://doi.org/10.1111/epp.12242

14. N. A. Didenko, M. E. Podgornaya, Fruit growing and viticulture of South Russia, 63(3), 240-253 (2020). https://doi.org/10.30679/2219-5335-2020-3-63-240-253

15. E. G. Yurchenko, G. V. Yakuba, M. E. Podgornaya, A. I. Nasonov, I. G. Mishchenko, A. V. Vasilchenko, Yu. P. Kashchits, Scientific works NCFSCHVW, 23, 176-180 (2019). https://doi.org/10.30679/2587-9847-2019-23-176-180 